\title{
Socio-Demographic Changes Among the Parsis in Delhi, India
}

\author{
Stuti Singh ${ }^{1}$ and Roumi Deb ${ }^{*}$ \\ ${ }^{1}$ Amity Institute of Anthropology, Amity University Uttar Pradesh, Noida sector-125, UP, India \\ ${ }^{2}$ HOD \& Addl. Director, Amity Institute of Anthropology, Amity University Uttar Pradesh, Noida sector-125, UP, India
}

*Corresponding author: rdev@amity.edu

Received: $16-08-2020$

Revised: $23-11-2020$

Accepted: 03-12-2020

\begin{abstract}
The Persian Zoroastrians who got refuge in India to protect themselves from Islamic persecution are well known as Parsis. Parsi is an ethno-religious community in India and are striving for their existence in contemporary society. Due to low birth rates, low marital fertility, inter-religion marriages the population is dwindling rapidly. The present study was conducted with an aim to understand the intra communal reasons for decrease in population and effect of migration on the ritual practices. The findings revealed that the dwindling numbers of Parsis is due to the negligence, less communal bonding and force among the people of the community. Also, the orthodox notion of blood purity has restricted community to accept the children of inter-religion marriages to follow the faith. In conclusion, the faith will tend to survive but Parsis will not and the population will tend to decline.
\end{abstract}

Keywords: Parsis, Demography, Migration, Health, Delhi

Parsis are a minority but an effervescent community that has maintained social isolation by practicing endogamy and not accepting any proselytes to the faith (Unisa et al. 2008). This community is closed and compact, which has fought against foreign domination and worked for social amelioration, had a dramatic origin (Sekar, 1948).

Zoroastrianism is a monotheist religion that originated in Iran. They are followers of Iranian prophet Zarathustra, dated back to the 1500 to 1000 BCE. During medieval times, Zoroastrianism was the dominant religion of Iran's three kingdoms - Achaemenian, Parthian and Sasanian. Zoroastrians migrated in India between the $8^{\text {th }}$ and $10^{\text {th }}$ century from Iran to rescue their community from the Islamic persecution (Visaria, 1974). Parsis were migrated from Iran to India in the $8^{\text {th }}$ century after their empire had been lost to Saracenic hordes. More than 3000 years ago, Zoroaster propagated his religion based on Good Thoughts, Good Words and Good Deeds. Beginning in the $10^{\text {th }}$-century, boatloads of Zoroastrian settlers, referred to as Parsis, migrated from Iran to India to seek new opportunities and flee, religious and economic persecution. Refugees were to remain exclusive as per an agreement with the local ruler in Gujarat; they promised not to convert anyone and adopt some local customs and practices (Vevaina, 2016). A group of Zoroastrians landed up in India on Gujarat's western coast (Jonnalagadda et al. 2011) who migrated to the Indian subcontinent around the $8^{\text {th }}$ century. Despite successfully integrating themselves into the Indian society, they have retained their ethnicity and distinct cultural practices.

How to cite this article: Singh, S. and Deb, R. (2020). Socio-Demographic Changes Among the Parsis in Delhi, India. Int. J. Soc. Sci., 9(04): 253-262.

Source of Support: None; Conflict of Interest: None (क) 9 
This study was conceived as a result of an excavation at the site of Sanjan, Gujarat which, as per historical records, is believed to be the first town in the Indian subcontinent with a large Parsi settlement thereby facilitating a diachronic comparison between the ancestral and extant Parsi groups. We compared and analysed dental traits between the two groups expecting a very close relationship between them owing to their ancestor-descendent relationship. Eleven discrete dental traits were selected and scored using the Arizona State University Dental Anthropology System. Parsis were predominantly found to be in Gujarat since they first entered India on the western coast of India (Desai, 1990).

For initial years they had taken shelter at the island of Diu then found refuge in the kingdom of Hindu king 'Jadi Rana.' Earlier, King refused migrants to give shelter due to lack of space in his kingdom by symbolizing it with a pot full of milk. The high priest of the community suggested a solution to him by dissolving sugar in the milk (Sudyka, 2019). This story indicated that the community would live peacefully and contribute to the kingdom's prosperity as sugar added the sweetness in the milk (Sudyka, 2019). Rana gave them refuge but based on certain conditions; they had to surrender their arms and weapons, speak the local language, wear same clothes as the other people of the territory, marriages and other rituals will take place after sunset and neither the forcible nor the voluntary religious conversions will be allowed.

One of earliest linguistic contact of the Parsis with the Indian subcontinent was established during the rule of Emperor Akbar. Akbar invited all the spiritual leaders from all over the country to attend his court. He had communicated with the head priest of Parsis in the Persian language (Langrial \& Baig, 2014). During the pre-colonial period, the Parsis did not exercise any unique influence on Indian society; they were primarily agriculturists and did some small scale business, including toddy trade. However, with the arrival of the Europeans, the Parsis completely redefined their identity by transforming themselves into a merchant community (Mathew, 2015; Palsetia, 2001). They became the favored minority due to the co-operative relations with the white men. Parsis learned business, trade and language from them. Gradually, this community became the middle man between the Indians and the British. However, later they realized that the status of the favored community they were enjoying was only for British people, and a vigorous sense of patriotism and revolutionaries like Bhikaji Cama came forward for the nation (Naskar, 2016).

According to India's census, the total population of Delhi in 2011 was 1.6 crore, where Parsis only contribute 950 people to the population of Delhi. The population of Delhi Parsis stands nowhere in comparison to the total population of Delhi. In Delhi, one of the oldest Parsi residences was of Nowrosji Kapadia. He came here from Bharuch, Gujarat, in 1880. He was the founder of Delhi Parsi Anjuman. For his pioneering role in the interest of the settlement of Parsis in Delhi, he was lauded. Few other families moved to Delhi during 1870-80. The majority of the Parsi population are urban dwellers. The first settlement Parsis made in Delhi was the early 19th century.

During the census of 1881, the population of Parsis was around 85,078. Until 1951, a slow and steady increase in the population of Parsis has been observed. Afterward, the Parsi population is encountering a significant decrease in the population. During the Census of India 2011, the Parsi population declined to 57,264 (Census of India, 2011). As the philanthropic contribution of Parsis is magnificent, therefore it will be terrible if the population dwindles at this rate. There are several social and biological factors behind the decrease in the population of Parsis. It involved concerns such as high literacy rate, inter-community marriages, late marriages, lower fertility rates. The first two extensive demographic types of research on the Parsi population were released within one year after independence. One of these studies entitled as A Community at the Cross-Roads conducted by Shapur Faredun Desai. Desai's work inspired an actual professional demographer $-C$. Chandra Sekar, affiliated by All India Institute of Hygiene and Public Health in Calcutta, to conduct a detailed study on the community (Pandey \& Yadav, 2015). No studies have been conducted on the demographic conditions and cultural changes of Delhi Parsis. The present study explored the factors affecting socio-demographic conditions and intra- 
communal reasons for Parsis's declining population in Delhi/NCR.

\section{Methodology}

The Parsi population is spread all over the Delhi/NCR region. Fifty Parsis were selected randomly. Data was collected using a structured schedule and in-depth interviews to gather detailed information. Subjects were informed about the purpose of research, and written consent was sought from each participant after informing them of the procedure thoroughly. Rapport was established among the subjects in order to collect information conveniently. The observation method was also used to get the insight information about the community. Data analysis was done by using the Statistical Package for Social Science (SPSS) version 16.0.

\section{RESULTS AND DISCUSSION}

\section{Socio-Demographic Profile of Parsi Community}

According to the represented Table 1, only 2\% respondents were falling into the category of 15-24 years, $12 \%$ subjects belonged to age group 25-34 years, $14 \%$ informants were from the age group of $35-44$ years, another $14 \%$ of the subjects were from the age group of $45-54$ years, $28 \%$ of the participants were from the age group of 55-64 years, and 28\% of the subjects belonged to elderly (65 years and above). This condition shows an inverted population pyramid of the community; in other words, there is no replacement for death rates in terms of birth rates. These deaths have exceeded births every year since 1955 . The study also determined that the community has approximately double proportions of females (68\%) than males (32\%).

The majority of the respondents (86\%) mentioned that they lived in the nuclear family; it is the norm in the community stated by $6 \%$ of them. Some of the respondents also considered it one of the reasons for decreasing numbers and degrading the community's family structures. Originally, Parsis were nonvegetarians, and in the present study, a large portion (96\%) of the participants were non-vegetarians. Most of the Parsis belonged to higher economic class and can afford the expenses of healthy living. This data depicted that $14 \%$ of the subjects were earning more than 100,000 Rupees per month, and on the other hand, 14\% did not reveal their monthly income. However, the study also revealed that $36 \%$ of the respondents were either pensioners or homemakers. People from this community were well educated and more career-oriented; that is why a considerable amount of them were graduates $54 \%$ and Post-graduate and above $42 \%$, respectively.

Table 1: Socio-demographic Profile of the Delhi Parsis

\begin{tabular}{|c|c|c|c|}
\hline Variables & & $\begin{array}{l}\text { Frequency } \\
\text { (n) }\end{array}$ & $\begin{array}{l}\text { Percent } \\
(\%)\end{array}$ \\
\hline \multirow{7}{*}{ Age } & $15-24$ years & 1 & 2 \\
\hline & 25-34 years & 7 & 14 \\
\hline & $35-44$ years & 7 & 14 \\
\hline & $45-54$ years & 7 & 14 \\
\hline & 55-64 years & 14 & 28 \\
\hline & 65 years and above & 14 & 28 \\
\hline & Total & 50 & 100 \\
\hline \multirow[t]{3}{*}{ Sex } & Male & 16 & 32 \\
\hline & Female & 34 & 68 \\
\hline & Total & 50 & 100 \\
\hline \multirow{7}{*}{$\begin{array}{l}\text { Age distribution } \\
\text { in Males }\end{array}$} & $15-24$ years & 1 & 6.25 \\
\hline & 25-34 years & 4 & 25 \\
\hline & $35-44$ years & 2 & 12.5 \\
\hline & 45-54 years & 2 & 12.5 \\
\hline & 55-64 years & 5 & 31.25 \\
\hline & 65 years and above & 2 & 12.5 \\
\hline & Total & 16 & 100 \\
\hline \multirow{7}{*}{$\begin{array}{l}\text { Age distribution } \\
\text { in Females }\end{array}$} & 15-24 years & 0 & 0 \\
\hline & $25-34$ years & 3 & 9 \\
\hline & 35-44 years & 5 & 15 \\
\hline & $45-54$ years & 5 & 15 \\
\hline & 55-64 years & 9 & 26 \\
\hline & 65 years and above & 12 & 35 \\
\hline & Total & 34 & 100 \\
\hline \multirow[t]{3}{*}{ Family Type } & Nuclear & 43 & 86 \\
\hline & Joint & 7 & 14 \\
\hline & Total & 50 & 100 \\
\hline \multirow[t]{3}{*}{ Dietary Habit } & Veg & 2 & 4 \\
\hline & Non-veg & 48 & 96 \\
\hline & Total & 50 & 100 \\
\hline
\end{tabular}


$\underset{A E S S R A}{J_{S}}$ Singh and Deb

\begin{tabular}{|c|c|c|c|}
\hline Monthly Income & Didn't disclose & 14 & 28 \\
\hline \multirow{5}{*}{ (₹) } & $20,000-60,000$ & 6 & 12 \\
\hline & $61,000-100,000$ & 5 & 10 \\
\hline & Above 100,000 & 7 & 14 \\
\hline & $\begin{array}{l}\text { Pensioners/ } \\
\text { Homemakers }\end{array}$ & 18 & 36 \\
\hline & Total & 50 & 100 \\
\hline \multirow[t]{4}{*}{$\begin{array}{l}\text { Educational } \\
\text { Qualification }\end{array}$} & $\begin{array}{l}\text { Senior Secondary } \\
\text { education }\end{array}$ & 2 & 4 \\
\hline & Graduation & 27 & 54 \\
\hline & $\begin{array}{l}\text { Post-Graduation and } \\
\text { above }\end{array}$ & 21 & 42 \\
\hline & Total & 50 & 100 \\
\hline \multirow[t]{4}{*}{ Marital Status } & Unmarried & 8 & 16 \\
\hline & Married & 40 & 80 \\
\hline & Widow & 2 & 4 \\
\hline & Total & 50 & 100 \\
\hline \multirow[t]{5}{*}{ Age at marriage } & Unmarried & 8 & 16 \\
\hline & $18-25$ years & 32 & 64 \\
\hline & 26-32 years & 8 & 16 \\
\hline & $33-40$ years & 2 & 4 \\
\hline & Total & 50 & 100 \\
\hline \multirow[t]{4}{*}{ Marriage type } & Unmarried & 8 & 16 \\
\hline & $\begin{array}{l}\text { Within the } \\
\text { community }\end{array}$ & 25 & 50 \\
\hline & $\begin{array}{l}\text { Inter-religion } \\
\text { marriage }\end{array}$ & 17 & 34 \\
\hline & Total & 50 & 100 \\
\hline \multirow[t]{3}{*}{ Migrant Type } & Permanent & 41 & 82 \\
\hline & Temporary & 9 & 18 \\
\hline & Total & 50 & 100 \\
\hline
\end{tabular}

A noticeable amount of people $(16 \%)$ in the community were found to be unmarried. More than half $(64 \%)$ of the Parsis got married at the age ranging from 18-25 years, i.e., favorable age for reproduction. There were only $4.0 \%$ of cases of late marriages in the studied population. However, this data is also not supporting the statement of the contribution of late marriages into decreasing people in the community. On the other hand, $52 \%$ of the people believed that late marriages are also the reason for the decrease in Parsis.

A high count of people $34.0 \%$ of the people married in other faiths due to which children of inter-religion marriages do not accept as the Parsis until there Navjote is not being done. The tabulated data represented that $82 \%$ of the subjects were permanent migrants, and $18 \%$ of the respondents were temporary migrants. The migration history indicated that Parsis are mainly city dwellers. Around (44\%) of the migrated Parsis came to Delhi in search of new opportunities for business or due to the job transfer. In the case of females, they mainly migrated due to the marriage and transferable professions of their husbands and fathers as the migration was the only reason behind Parsis's existence in India. Almost half (42\%) of the subjects agreed that migration had affected their cultural and ritualistic practices in specific ways. However, $46 \%$ of the subjects disagreed with the cultural changes due to migration and argued that Parsi culture could sustain even in metropolitans where life is very forward-moving, and the rest of the $12 \%$ of the participants did not mention about any cultural change that has been occurred due to migration.

\section{Health Seeking Behaviour of the Parsi Community}

Table 2 revealed that approximately $71 \%$ of the respondent attained menarche at the age of 11-13 years, $23 \%$ of the participants informed that they attained menarche at the age of $14-16$ years, and only $6 \%$ of them attained menarche at the age of 17 years and above. Age of menopause was informed $40-44$ years by $18 \%$ of female subjects, $41 \%$ informants mentioned $45-49$ years as the age of menopause, and $20.5 \%$ of the female respondents achieved menopause of 50-54 years. On the other hand, $20.5 \%$ of the females did not attain menopause till now. There was 100\% institutional delivery in the community, an excellent sign of awareness about institutional deliveries and mother/child health concern.

In the case of present illness, $32 \%$ of the people were suffering from other diseases. The most common health issues were Blood Pressure, Diabetes, and Cancer. However, $68 \%$ of the subjects were healthy. Only $10 \%$ of the respondents have informed them that they had a medical history, and the rest $90 \%$ denied any medical history. In the family's health profile, $68 \%$ of the participants had informed that no family member is suffering from any illness. 
A tiny proportion (12\%) of the subjects were aware of the genetic screening and had done for their children, such as G6PD deficiency test and Chronic Villus sampling, to check genetic mutation's possibility. The remaining proportion $(88 \%)$ of the respondents were not aware of genetic screening. The majority, $96 \%$, were not availing any health benefits from the government; instead, they had their medical insurance, and only $4 \%$ of people were availing health benefits provided by the government. A significant amount of $68 \%$ of subjects were able to go for regular health check-ups. However, $32 \%$ of the participant were not going for regular health check-ups.

The prevalence of smoking comparatively less than alcohol, $16 \%$ of the informants stated that they have a smoking habit. In Parsi, community liquor plays a significant role in social gatherings; it is considered the bonding agent. Hence, the present data revealed that most Parsis $(76 \%)$ enjoy consuming alcohol.

Table 2: Health Seeking Behaviour of the Delhi Parsis

\begin{tabular}{|c|c|c|c|}
\hline Variables & & $\begin{array}{l}\text { Frequency } \\
\text { (n) }\end{array}$ & $\begin{array}{l}\text { Percent } \\
(\%)\end{array}$ \\
\hline \multirow{4}{*}{$\begin{array}{l}\text { Age at } \\
\text { Menarche }\end{array}$} & $11-13$ years & 24 & 71 \\
\hline & 14-16 years & 8 & 23 \\
\hline & 17 years and above & 2 & 6 \\
\hline & Total females & 34 & 100 \\
\hline \multirow[t]{5}{*}{$\begin{array}{l}\text { Age at } \\
\text { Menopause }\end{array}$} & $\begin{array}{l}\text { Didn't attain } \\
\text { menopause }\end{array}$ & 7 & 20.5 \\
\hline & 40-44 years & 6 & 18 \\
\hline & $45-49$ years & 14 & 41 \\
\hline & 50 years and above & 7 & 20.5 \\
\hline & Total females & 34 & 100 \\
\hline \multirow{3}{*}{$\begin{array}{l}\text { Child birth } \\
\text { delivery }\end{array}$} & Hospital & 28 & 100 \\
\hline & Others & 0 & 0 \\
\hline & Total females & 28 & 100 \\
\hline \multirow[t]{3}{*}{ Present Illness } & Yes & 16 & 32 \\
\hline & No & 34 & 68 \\
\hline & Total & 50 & 100 \\
\hline \multirow[t]{3}{*}{ Past Illness } & Yes & 10 & 20 \\
\hline & No & 40 & 80 \\
\hline & Total & 50 & 100 \\
\hline
\end{tabular}

\begin{tabular}{|c|c|c|c|}
\hline \multirow{3}{*}{$\begin{array}{l}\text { Under-going } \\
\text { treatment }\end{array}$} & Yes & 16 & 32 \\
\hline & No & 34 & 68 \\
\hline & Total & 50 & 100 \\
\hline \multirow{5}{*}{$\begin{array}{l}\text { No. of family } \\
\text { members } \\
\text { suffering from } \\
\text { any illness }\end{array}$} & None & 34 & 68 \\
\hline & One & 8 & 16 \\
\hline & Two & 7 & 14 \\
\hline & Three & 1 & 2 \\
\hline & Total & 50 & 100 \\
\hline \multirow{3}{*}{$\begin{array}{l}\text { Genetic } \\
\text { screening for } \\
\text { children }\end{array}$} & Yes & 6 & 12 \\
\hline & No & 44 & 88 \\
\hline & Total & 50 & 100 \\
\hline \multirow{3}{*}{$\begin{array}{l}\text { Fertility } \\
\text { Assessment }\end{array}$} & Yes & 9 & 18 \\
\hline & No & 41 & 82 \\
\hline & Total & 50 & 100 \\
\hline \multirow{3}{*}{$\begin{array}{l}\text { Availing } \\
\text { health } \\
\text { benefits from } \\
\text { Government }\end{array}$} & Yes & 2 & 4 \\
\hline & No & 48 & 96 \\
\hline & Total & 50 & 100 \\
\hline \multirow{3}{*}{$\begin{array}{l}\text { Regular } \\
\text { Health check- } \\
\text { ups }\end{array}$} & Yes & 34 & 68 \\
\hline & No & 16 & 32 \\
\hline & Total & 50 & 100 \\
\hline \multirow{3}{*}{$\begin{array}{l}\text { Smoking } \\
\text { Habit }\end{array}$} & Yes & 8 & 16 \\
\hline & No & 42 & 84 \\
\hline & Total & 50 & 100 \\
\hline \multirow{3}{*}{$\begin{array}{l}\text { Alcohol } \\
\text { consumption }\end{array}$} & Yes & 38 & 76 \\
\hline & No & 12 & 24 \\
\hline & Total & 50 & 100 \\
\hline
\end{tabular}

\section{Assessing the Reasons for Decline in Parsi Population}

According to researchers, social scientists and anthropologists, several sociological and biological factors affect the Parsi population in India. Predominantly, late marriages, inter-religion marriages, and low marital fertility were discussed as the reasons for the decrease in Parsi population.

As Fig. 2 has shown, over 52\% of subjects agreed that late marriages are the reason for the Parsi population's decline. Late marriages are prevalent due to the reason that Parsis are progressive mind, and place a high onus on education and standard of living (12). There are 
several associated consequences of late marriages; late marriages result in lower marital fertility and eventually, less or no children, contributing to the lower birth rates in the community. However, in the present study, only $4 \%$ of cases had late marriages, so it did not support that late marriage as the reason for the decrease in the Parsi population.

Marriage is not very common among Parsis, and 34\% of the respondents reported that this is one reason for the dwindling population of Parsis. Moreover, late marriage is another reason for less population among this group.

There is no communal force in the Parsi community for getting married; $14 \%$ of the respondents supported this statement and contributed to the late marriages and no marriages. $10 \%$ of the participants informed that the younger generation is more concerned about achieving higher education and a stable career.

Fig. 1 revealed that $38 \%$ of the respondents that interreligion marriages cause a downfall in the community.
The reason behind that is Parsis do not live in proximity; hence there are very few chances to meet Parsis. Less Orthodox Parsis do not believe in arranged marriage; instead, they prefer a partner of choice or love marriage. However, finding compatible matches in the community is also very difficult. About $18 \%$ informants also shared that Parsi women are well educated compared to their male counterparts, thus finding suitable partners according to their demand is an uphill task. However, it contributes to late marriages, no marriages and interreligion marriages and associated issues such as nochild-couple or one-child couples in the community. Since in the case of Parsi women marrying outside the community, the offspring from inter-religion marriages will not be accepted as Zoroastrians because patriarchy rules in the community; hence people believe that a child will tend to follow father's religion as informed by key informants (Shroff \& Castro, 2011). As the liberal thoughts are prevalent in Delhi, Parsis gave rise to the new tradition in the community by accepting

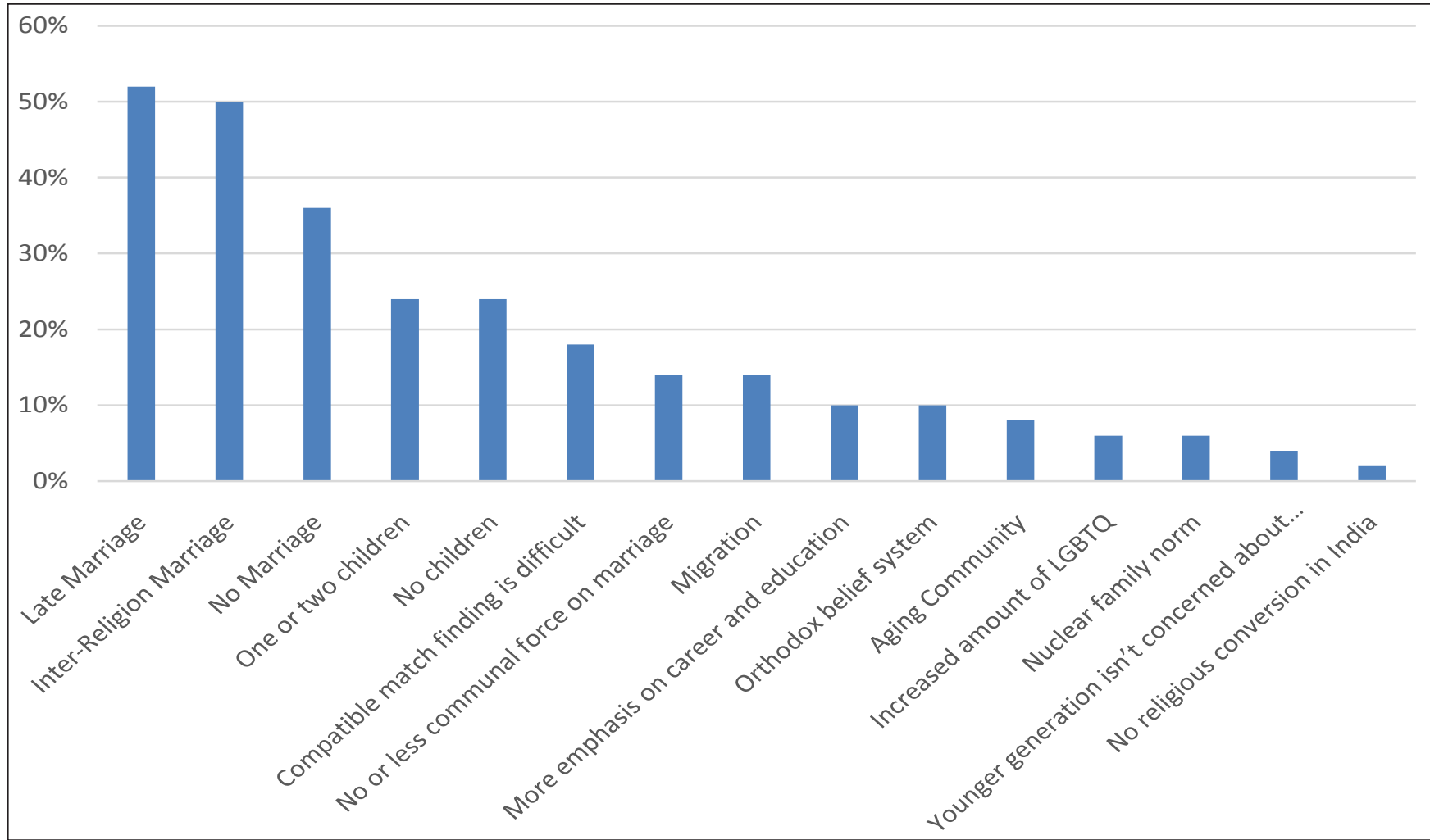

Fig. 1: Intra-communal reasons contributing in decrease in Parsi population v/s Percentage (\%) of people responded 


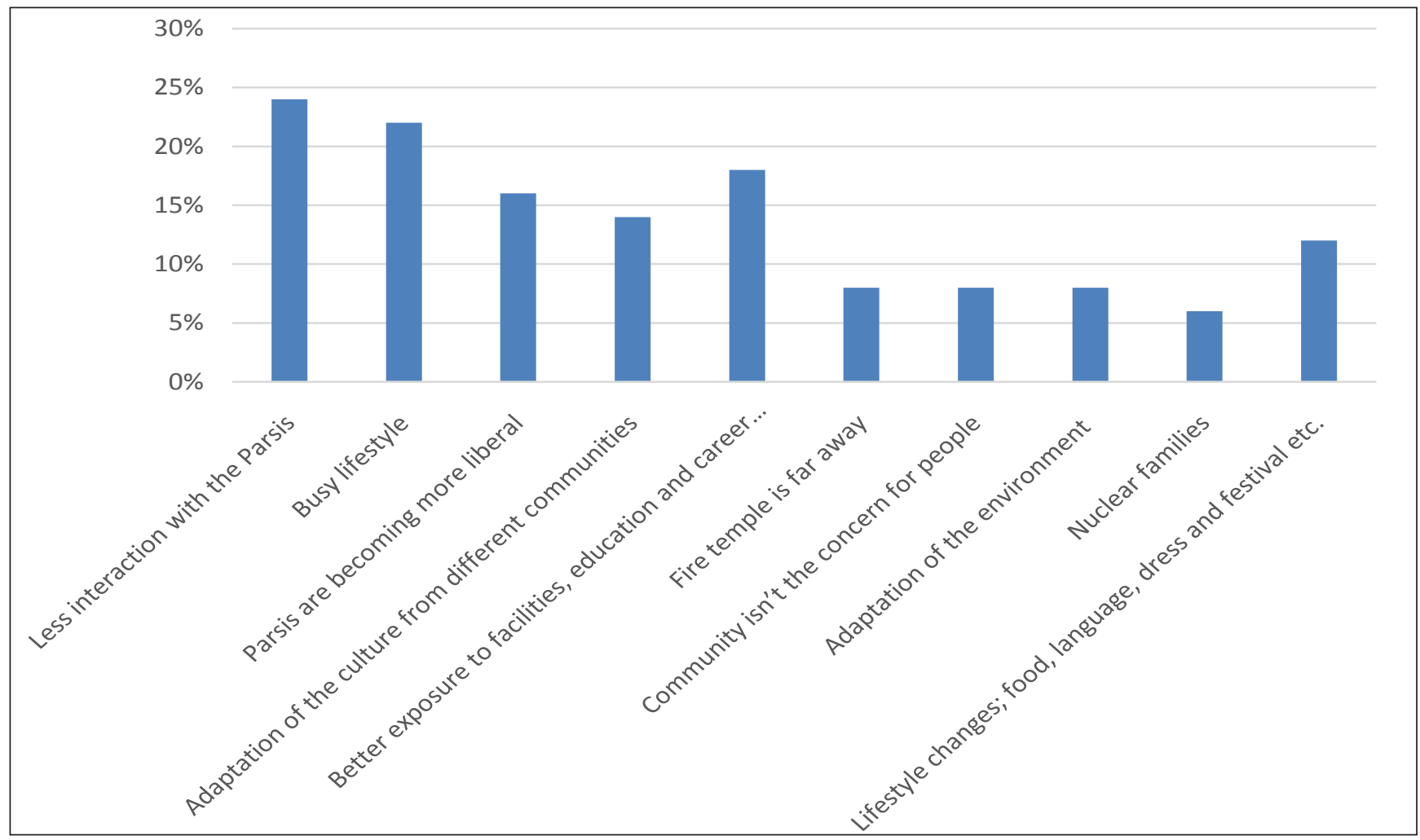

Fig. 2: Influence of modern metro cities on the Parsi Community v/s Percentage (\%) of people responded

the children who have a single Parsi parent with the consent of the non-Parsi partner. However, the high priest of Delhi Parsi Anjuman is still not performing Navjote for inter- faith marriage couple's children. Late marriage and no marriage consecutively bestowed in one-child or no child couple. Less child and no child are represented in Fig. 1 as the dwindling by $24 \%$ of the people. Communal force is ensuring the social sanction in the community, but in Parsis, as stated by $14 \%$ of the participant, there is no or very less communal force on marriage i.e., people do not emphasize getting married.

Migration is ubiquitous to this community due to the influence of western culture. Migration was considered one of the reasons for the decline in the number of Parsis; the reason is that many males leave India for higher education and seldom return (Pandey \& Yadav, 2015). The conventional belief system contributes to the decrease in the population of the Parsis opinionated by $10 \%$ of the subjects. Constant conflicts are occurring among orthodox and liberal Parsis of the community.
According to the orthodox belief system, one should be born as a Parsi to be a part of the community, and there will be no proselytization into Zoroastrianism. To maintain blood purity, orthodox Parsis do not support the acceptance of children of a single Parsi parent in the Zoroastrian faith. Orthodox Parsis also believe in marrying within the community; there is no further question of choice for the partner. Parsi Community is an aging community because of the lowering of birth rates. Since there is no replacement for aged people due to lower birth rates, it undoubtedly contributes to the dwindling number of Parsis.

Some informants affirmed that acceptance of LGBTQ is also the reason for the decrease in marital fertility. As Parsis are broad-minded, people from LGBTQ are welcomed with open arms, which is a beautiful gesture towards the marginalized proportion of society but down the lane contributing to the community's downfall. As opined by $6 \%$ of the subject's nuclear family is a norm in the community. Informants believed that 
the two reasons behind this are that firstly, the younger married couple does not stay with their family to avoid conflict between daughter in law and mother in law. Secondly, migration due to professions also plays a role, and these couples tend to have fewer or no children. A tiny proportion of the targeted population mentioned that upcoming generations are not concerned that prohibition on religious conversion into Zoroastrianism in India is responsible for the community's downfall.

\section{Changes in Rituals and Beliefs of the Community Due to Migration}

Parsis are urban dwellers; about $24 \%$ of the subjects informed that in metro cities, they have very little interaction with Parsis compared to Gujarat and Mumbai. However, 22\% of the people mentioned the reason behind lesser interaction is the people's busy lifestyle in metropolitans.

As the liberal thoughts are very prevalent in the community, $16 \%$ of the respondents agreed that migrating to Delhi played a significant role in the liberalism of the community. Hence, they claimed that Delhi Parsis are more liberal. It has been visible in their acceptance towards children of the inter-religion marriage and adopting crematorium or burial for the deceased's death ritual whereas earlier corpse were suspended at Death Tower (Dakhma) for vultures to feed on them (Anton, 2016). Cultural adaptations from other cultures are also there as Delhi is the multicultural region; hence, every culture influences the other culture. This statement was stated by $14 \%$ of the respondents. Cultural adaptations also influence eating habits, dress, and celebrating festivals; this statement was supported by $12 \%$ of the participants.

Delhi has better exposure and access to education, job and career opportunities, $18 \%$ of the informants stated this as the reason behind migration. Some of the participants also shed light on the negative side of the influence of the metro cities were $8 \%$ of the subjects responded that in Delhi, people are less concerned about the community due to their own busy life, negligible behavior towards the community. The nuclear family is the norm in the community as informed by $6 \%$ of the participants, and $8 \%$ of the subjects also mentioned that the fire temple is far away, going there and meeting Parsis of the community is a difficult task. Hence, contributing to lesser interaction among the community members, which is also a reason behind Delhi Parsis losing their communal bonding.

The present study concentrated on ascertaining the Parsi community's demographic profile in several aspects related to the declination in their population. Census data and specially designed demographic studies enumerated that late or no marriages, and low marital fertility was the primary cause of the decline (Axelrod, 1990). However, in contemporary studies, there are few more associated reasons with dwindling numbers of Parsis.

According to Chandra Sekar (1948), Parsis's age structure since the early $20^{\text {th }}$ century has undergone several changes, but it has shown resemblance to that of England and Wales (Sekar, 1948). In the present study, the population of the elderly was quite high. According to E.B. Gustafson (1969), the Parsi population of Pakistan also showed the lower birth rates that cannot replace death rates (Gustafson, 1969). A nuclear family is a typical practice in the Parsi community, which impacts family structures and the elderly population of the community. Nuclear family norm has also led to several criminal cases with older adults of the community, and it is a tough job for the community to take care of those elderly people. Monthly income does not show any significant relationship with the age structure, marriage pattern and migration. However, it has quite an essential role in the health-seeking behavior of the people. Parsis can afford medical insurance and treatment in Private hospitals. Parsi is a well-educated community; education is the key to upward mobility and community evidence this statement.

Marriage is a vital institution in the building of a community. From the 19th century, researchers are studying how marriage contributes to the population growth of the community. According to P. Axelrod (1990), marrying at a late age is not foreign to the Parsis (Axelrod, 1990). According to the census of 1901, half of the married at the ages over 20. Non-marriage is also considered as the result of late marriage. It seems to 
be right in the case of Parsis. In the study of S. Unisa (2008), the primary reason for non-marriage and late marriages was the concern of young males and females in accepting the minimum standard of living for family formation (Unisa et al. 2008; Visaria, 1974). In findings of present studies, late marriages are prevalent in the community due to young people's concern to achieve a better career and educational qualification; finding Parsis in proximity is rare; therefore, marrying or dating a Parsi seems impossible. These scenarios lead to late marriages or often no marriages in the community. Late marriages result in lower marital fertility (as there is no such biological infertility present in the community) and gradually contribute to the lower or no population replacement.

The community's conventional belief system is also contributing to the smaller number of people in the community. To maintain the purity of race, orthodox oppose accepting the offspring of a girl's marrying outside the community, while this is not the case with the males. It showed that the patriarchy still rules in the community. LGBTQ is also welcomed in the community indirectly; it also contributes to the declining numbers of the Parsis because the count of reproductive individuals will decrease and affect the community's fertility rate. S. Unisa (2008) stated that along with marriage, voluntary and involuntary childlessness is another factor for the low fertility among the Parsi community (Unisa et al., 2008).

Delhi is a multicultural region and has an intercultural impact on every existing community. Delhi Parsis claimed that they are more liberal in comparison to Parsis of Gujarat and Mumbai. Delhi Parsis adopted several new traits from other communities, and it also enhances the rate of marrying from other communities. Inter-religion marriages also come with enculturation. Migrating to metro cities also has a significant influence on the people's rituals and practices; traditional ways of performing ceremonies are fading away in the cities. As a result, people opting for natural and less timeconsuming ways of performing rituals.

Parzor foundation in their UNESCO funded project lead by Dr. Shernaz Cama is working on how to conserve the
Parsi culture and population. Parzor is looking into the specific issues related to the community; alarmingly low fertility, late and no marriages, inter-religion marriages and divorces. This foundation is also trying best to conserve the traditional Parsi culture by conducting workshops for children and adults' counseling. Ministry of Minority affairs also developed the 'JIYO PARSI' scheme to promote and conserve the culture of Parsis (Ministry of Minority Affairs, 2018).

\section{CONCLUSION}

In the present study, the community's demographic conditions conclude that the population pyramid is inverted in the Parsi community due to the higher death rates and lower birth rates. An aging population is a concern for the community. Considering the elderly's situations, they are facing a lack of family support, health problems, and crimes. If such a neglecting outlook of the people towards their community will carry on, it might lead to Parsis becoming a tribe after a few decades. The conservation of this ethnic group is mandatory regarding their contribution to the building of the nation.

The diminishing numbers of Parsis are based on an individual level rather than a social or communal force. In this community, there is nothing like public pressure on the people to live in a certain way. They believe in living in harmony; hence, the dying population's concern has a lesser impact on the community. The younger generation shows very little communal bonding, which is a concerning issue for the older generation. It will lead to weak family structures in the community. Eventually, the community will shatter into pieces.

Parsis will die out, but Zoroastrians will tend to live. This statement is an unavoidable truth because all Parsis are Zoroastrians, but not all Zoroastrians are Parsis. In other words, an individual can be proselytized into Zoroastrian but cannot become a Parsi. In conclusion, it may be stated that "Ethnicity will lose its roots, but faith will tend to thrive." This study can be utilized for comparative analysis for Parsis' demography living in different parts of the country and their perceptions about the community. This can be an essential dimension of studying this population because intra-communal 
factors govern the conservation of their culture. It can also be used as a reference to study ritualistic changes in the Parsi community due to the migration.

\section{REFERENCES}

Anton, Z. 2016. Zorastrian Funeral Practices: Transition in Conduct. In Threads of continuity: Zoroastrian Life \& Culture (p. 400).

Axelrod, P. 1990. Cultural and historical factors in the population decline of the parsis of India. Population Studies. https://doi. org/10.1080/0032472031000144826

Census of India. 2011. Provisional Population Totals NCT of Delhi (pp. 59-80). http://www.censusindia.gov.in/2011-prov-results/ data_files/delhi/3_PDFC-Paper-1-tables_60_81.pdf

Desai, S. 1990. A Community at the Cross Roads. https://zoroastrians. net/wp-content/uploads/2019/01/a-community-at-the-crossroad.pdf

Gustafson, E.B. 1969. A demographic dilemma: the Parsis of Karachi. Social Biology, 16(2): 115-127.

Jonnalagadda, M., Ozarkar, S. and Mushrif-Tripathy, V. 2011. Population affinities of Parsis in the Indian subcontinent. International Journal of Osteoarchaeology. https://doi.org/10.1002/ oa.1123

Langrial, A.H. and Baig, M.A. 2014. Zoroastrians in Mughal Court: A short study of Parsis and their rise in Mughal India. Al-Adwa, 42(49): 55-70.

Mathew, M. 2015. Ethnic conflict and the Fate of Parsis in India: a Study of Rohinton Mistry's Tales from Firozshah Bag. IOSR Journal of Humanities And Social Science. https://doi. org/10.9790/0837-20456064
Ministry of Minority Affairs. 2018. "JIYO PARSI" (Issue September).

Naskar, S. 2016. Vanishing point: The last remaining parsis of Delhi. The Sunday Guardian. https://www.sundayguardianlive.com/ culture/6714-vanishing-pointthe-last-remaining-parsis-delhi

Palsetia, J. 2001. The Parsis of India: Preservation of Identity in Bombay City. https://books.google.co.in/ books?hl=en\&lr=\&id=R6oNt3M_yLgC\&oi=fnd\&pg $=$ PR $9 \& d q=A k b a r+a n d+P a r s i s+\operatorname{connect\& ots}=c W 3 k_{-}$ E57wj\&sig=eJxbsBt1NpqGuS-yae1Gz-OX6Ug\&redir_ $\mathrm{esc}=\mathrm{y} \# \mathrm{v}=$ onepage $\& \mathrm{q} \& \mathrm{f}=$ false

Pandey, R. and Yadav, N. 2015. Fertility Decline: A Statistical Demographic Review of Parsi Community. Bulletin of Mathematics and Statistics Research, 3(4): 104-122.

SEKAR, C.C. 1948. Some aspects of Parsi demography. Human Biology; an International Record of Research.

Shroff, Z. and Castro, M.C. 2011. The potential impact of intermarriage on the population decline of the Parsis of Mumbai, India. Demographic Research, 25: 545-564.

Sudyka, L. 2019. "Like Sugar in Milk": Zarathustrians in Pune. Studia Litteraria Universitatis Iagellonicae Cracoviensis, 14(Special Issue): $245-256$.

Unisa, S., Bhagat, R.B., Roy, T.K. and Upadhyay, R.B. 2008. Demographic transition or demographic trepidation? the case of Parsis in India. Economic and Political Weekly.

Vevaina, L. 2016. Good thoughts, Good words and Good (Trust) Deeds. In Handbook of Religion and the Asian City (pp. 152-167). https://doi.org/10.1525/california/9780520281226.001.0001

Visaria, L. 1974. Demographic Transition among Parsis: 18811971: I: Size of Parsi population. Economic and Political Weekly, 9(41): 1735-1741. 